\title{
The initial natural ${ }^{36} \mathrm{Cl} / \mathrm{Cl}$ ratio in the aquifer recharge over North Africa and Arabia
}

\author{
PIERRE DESCHAMPS, BRUNO HAMELIN AND JULIO \\ GONCALVES
}

CEREGE, Aix Marseille Univ, CNRS, IRD, INRAE, Coll France

Presenting Author: deschamps@cerege.fr

With its half-life of $301 \mathrm{ka}$, the ${ }^{36} \mathrm{Cl}$ cosmonuclide provides an invaluable chronometer to constrain the residence time of groundwater in large aquifer systems. In the hydrosphere, ${ }^{36} \mathrm{Cl}$ originates mainly from spallation of argon in the atmosphere. In addition to this continuous natural production, large amounts of ${ }^{36} \mathrm{Cl}$ were also produced in the 50 's by neutron activation of seawater chloride during atmospheric testing of thermonuclear weapons. As evapotranspiration processes impact the ${ }^{36} \mathrm{Cl}$ content during groundwater recharge, ${ }^{36} \mathrm{Cl}$ is generally normalised to chloride, particularly in studies of semi-arid to arid regions. Using the ${ }^{36} \mathrm{Cl} / \mathrm{Cl}$ ratio, it becomes easier to separate the ${ }^{36} \mathrm{Cl}$ decrease due to radioactive decay from other processes, although other complications may arise from the presence of Clrich evaporites in the reservoir rocks. Therefore, a crucial step in using ${ }^{36} \mathrm{Cl}$ as a hydrological tracer is to assess the preanthropogenic initial ${ }^{36} \mathrm{Cl} / \mathrm{Cl}$ ratio $\left(\mathrm{R}_{0}\right)$ of water recharging the aquifer system. For a given site, $\mathrm{R}_{0}$ depends both on the natural cosmogenic production and washout of ${ }^{36} \mathrm{Cl}$ in the atmosphere and on the average chloride concentration in precipitation. A ${ }^{36} \mathrm{Cl} / \mathrm{Cl}$ ratio above this initial ratio is then indicative of the presence of anthropogenic ${ }^{36} \mathrm{Cl}$ in groundwater, thus of active recharge into the aquifer, while ${ }^{36} \mathrm{Cl} / \mathrm{Cl}$ ratio below this value indicates ${ }^{36} \mathrm{Cl}$ decay, and opens the possibility to ${ }^{36} \mathrm{Cl}$ age determination.

For the last 10 years, the CEREGE group has conducted several ${ }^{36} \mathrm{Cl}$ studies of various aquifer systems over Northern Africa and Arabia (North West Sahara Aquifer System, Nubian Sandstone Aquifers in Chad and Saudi Arabia, Continental Intercalaire of the Iullemeden Bassin, Quaternary Aquifers in Lake Chad Basin) by using the $5 \mathrm{MV}$ ASTER AMS facility. The initial ${ }^{36} \mathrm{Cl} / \mathrm{Cl}$ ratios range from $300.10^{-15}$ at/at in Niger to $\sim 100.10^{-15}$ at/at in Tunisia. In this communication, we will discuss the main processes controlling $\mathrm{R}_{0}$, including the natural distribution of ${ }^{36} \mathrm{Cl}$ deposition and the variation in chloride concentration in precipitation, and thus the chloride cycle at the scale of North Africa and Arabia. 